\title{
Racial Ideology of Mestizaje and its Whitening Discourse in Memín Pinguín
}

\author{
Paloma Fernández Sánchez \\ Columbia College \\ South Carolina, United States
}

\begin{abstract}
In this essay I will analyze how the comic strip Memin Pinguin, applying Vasconcelos' The Cosmic Race framework of mestizaje, presents an apparent harmonious yet deceitful image of racial democracy which ultimately reveals a whitening discourse. Though different races are given a space in this comic strip, their representation is far from even and the white character(s) are clearly privileged. The black characters-exclusively represented by Memín and his mother Eufrosina-are portrayed as physically and intellectually inferior and with no agency. Their actions are measured and directed by authority figures-which are racially white. Those authority figures judge Memín and his mother's actions as mostly illogical or incorrect. All in all, these opinions reduce blackness to a minimal presence which has no repercussion on the others' lives, in addition to presenting blackness as a recessive trait that will eventually disappear. The (mis)representation of the black presence and contribution to the Mexican society in the comic strip follows the same standards which are applied on a daily basis in Mexico. While the visual elements of the comic strip provide the reader with an apparent inclusive image parallel to the one proclaimed by mestizaje, the discourse and character interactions incorporate other less all-encompassing dynamics.
\end{abstract}

Key words: mestizaje, whitening discourse, ideology, México, racial identity

\section{Resumen}

En este artículo se analizará cómo la tira cómica Memín Pinguín, según la teoría del mestizaje de La razón cósmica de Vasconcelos, presenta una imagen de la democracia racial aparentemente armoniosa y engañosa que, en última instancia, revela un discurso sobre el blanqueamiento. A pesar de que diferentes razas tienen un espacio en la tira cómica, su representación es escasa y los personajes blancos son los más representados. Los personajes negros -representados exclusivamente por Memín y su madre Eufrosina- son retratados como física e intelectualmente inferiores e instrumentales. Sus acciones son juzgadas y dirigidas por figuras de autoridad racialmente blancas. 
Estas figuras consideran las acciones de Memín y de su madre como ilógicas o incorrectas generalmente. De todas maneras, estas mismas figuras reducen la negritud a una presencia mínima, sin repercusión en las vidas ajenas, además de presentarla como un rasgo recesivo que iría a desaparecer. La no-representación de la presencia negra ni de su contribución a la sociedad mexicana sigue los mismos estándares aplicados diariamente en México. Mientras los elementos visuales de la tira cómica ofrecen al lector una aparente imagen inclusiva semejante a la que proclama el mestizaje, el discurso y las interacciones de los personajes introducen otras dinámicas menos inclusivas.

Palabras claves: mestizaje, discurso de blanqueamiento racial, ideología racial, México

I $\mathrm{t}$ is the first day of class in an elementary school in Mexico and students crowd the classroom. Among the group of students, Guillermo — a very light skinned ${ }^{1}$, welldressed boy with blond hair sits at the back of the classroom. Ernesto-a slim boy with straight black hair and no shoes, and Carlos-a boy with brown curly hair, slightly thicker lips and a snub nose-share the second row. In the middle of the classroom is Memín-a bald black tiny boy. This image is the introduction to the first episode of the popular Mexican comic strip Memin Pinguin,--first published in the 1940s and still in print-which presents the classroom as a microcosm of Mexico's mestizo society. Guillermo, Ernesto, Carlos and Memín represent the current Mexican national imagined community in which its different members feel represented in one of the main protagonists. For Benedict Anderson, the nation is "an imagined community, because, regardless of the actual inequality and exploitation that may prevail in each, the nation is always conceived as a deep, horizontal comradeship" (7). Thus, each individual-in spite of his/her race would feel in communion with the rest. Therefore, the indigenous, black and white races are supposed to mingle and coexist in that imagined immemorial community. However, as the adventures of Memín and his friends unfold in the comic strip, conflicts arise and the apparent racial harmony fractures showing the inconsistencies of that horizontal equality claimed by the discourse and the imagined community of mestizaje. This situation is once again an illustration of Mexico's long history of misrepresentation of blacks since colonial times.

This difference between the discursive imagined community of the nation and the actual dynamics among its members is a rather truthful representation of Mexico's dealings with race for at least the last century. Once the Revolution was over, a new national unifying identity was created and imposed on the population. At that historical moment Mexico started to conceive itself as a mestizo society, giving an apparent but misleading image of harmonious multiplicity and equality among or between the races in the country. Though in the 1920s mestizaje was new as national consciousness, it 
was presented as ahistorical looking "out of an immemorial past, and, still more important, glide[ing] into a limitless future." (Anderson 11-12). By presenting mestizaje as an ever-presence in Mexico, the intellectual elite along with the new Mexican states successfully overpower other racial expressions. Mestizaje and its process of racial and cultural fusion fostered the image of a conglomeration of racesthe mestizo - that indeed lead to an atmosphere of delusion. Therefore, mestizaje has made Mexico discursively colorblind, not by erasing race, but by ignoring and therefore denying races any possible political and social representation. When this discourse-articulated by the intellectual elite and promulgated by mass media and government officials-is contrasted with everyday reality, one begins to see the contradictions and the empty spaces that attest to the many racial frictions and suppressions that are overlooked or ignored by most of those educated and living within the ideological discourse.

The comic strip Memin Pinguin ${ }^{2}$ is an excellent example of this double edged reality where one side creates the illusion of an imagined homogeneous fraternity based on equality and the other one hides the practices of a racial ideology. The comic strip was created during the $1940 \mathrm{~s}$, the high point of mestizo aesthetics. This was a time period when people were being bombarded through different popular cultural representations that the mestizo is more beautiful, stronger, virtuous, and all other manner of superlatives. Memín Pinguín, through the depiction of an inclusive and mixed classroom actively participated on the spread of this mestizo aesthetic. Its format -a comic strip-, and its accessibility may have been the reasons why, several years after its initial weekly publication, the comic strip had achieved a very high popularity and a circulation of more than two hundred thousand copies a week (Aurreconechea). It became a milestone of comics in Mexico during the 1940s. Juan Manuel Aurreconechea and Armando Bartra, two comic strip book historians, declared Memin Pinguin as one of the biggest best sellers of Mexican comic strip. In the1960s, Memín was exported to other Latin American countries: Colombia, Costa Rica, Ecuador, El Salvador, Guatemala, Honduras, Panamá, Puerto Rico, and the Dominican Republic where the comic strip attained various publication successes (Hernandez 53). In fact, even though its author, Vargas Dulche and the illustrator Sixto Valera stopped producing new stories in the 1990s, there have been-and still are-several reprints. Today, anyone can walk to a kiosk to buy Memín in Mexico. I argue that it is due to this popularity and success that Memin Pinguin has been and is a powerful popular element that perpetuates a whitening tradition. In other words, this popular representation of Mexican imagined multiethnic reality claimed and celebrated $^{3}$ by Mexico officials and intellectuals rather than opening a space for equal racial interaction perpetuates mestizaje whitening discourse as presented by Vasconcelos in The Cosmic Race.

The (mis)representation of blackness in Memín is far from an isolated example; it follows a long tradition starting with the first black populations in Mexico right after the arrival of Hernán Cortés in 1519. Taking this 
into consideration, I will first briefly present the history of misrepresentation that black populations have undergone in this country since colonial times. Then, I will revisit the concept of mestizaje and the different ways in which it also undermines blackness in favor of other races-mainly white. Finally, I will analyze the role assigned to blackness in the mestizo society staged in the comic. The study of racial dynamics in Mexican popular cultural productions during the heyday of mestizo nationalism allows individuals to see how the image of the Mexican nation and the racial ideals articulated by post-revolution intellectuals were not a simple description of the society but an imposition of a mythical homogeneity which was - and still is - far from actual reality.

Blacks are not a new race to Mexico; their presence goes back to colonial times. According to the chronicles and letters of the conquistadores, the first Spaniards to set foot in the New World brought black people with them ${ }^{4}$. Pedro de Alvarado, Pánfilo de Narváez and Francisco de Montejo among others included a considerable number of blacks in their expeditions (Aguirre 20). During the first years of settlement, blacks were brought from Spain, but they soon began to be imported from the Antilles. There was a vast land to be conquered and the conquistadores needed bodies to fight for it and farm it. Aguirre points out that due to this practice, in less than fifty years, the presence of blacks grew from a few hundred to hundreds of thousands in the Virreinato de la Nueva España ${ }^{5}$. However, despite their relative high presence, their actual population has been repeatedly mis-represented or miscalculated. Alejandro de Humboldt, in his census stated that the total number of Africans in 1570 was 6100. Based on these numbers, he concluded that "habiéndose introducido en la Nueva España poquísimos negros, los mestizos componen probablemente los 7/8 de la totalidad de las castas"6 (Humboldt 23). Humboldt's records are extremely relevant for two reasons: first, they reveal a long tradition of distortions when accounting for the black presence in Mexico; second, they show that the concept of mestizaje was already in circulation early in the colonial period.

Aguirre Beltrán in his study La población negra en México revisits Humboldt's analysis and other censuses from the 16 th to the 18 th centuries to put in perspective the numbers they provide and prove that, in fact, the proportion is higher and even more relevant than once thought. According to Aguirre, Humboldt's assertion regarding the presence of different races in Mexico at that time, is incorrect and excludes many essential variables ${ }^{7}$. Even if there were only 6100 black people, that number represents $71 \%$ of the total population which immigrated to the area at that time. Therefore, by the end of the $16^{\text {th }}$ Century, only $21 \%$ of the people who had come to Mexico were white (Aguirre 198). Additionally, during that time, the high levels of miscegenation quickly lead to a mixed population. The black and white binarism was soon unable to account for the wide spectrum of colors present in the society. Therefore, a system of castes was implemented to classify the population according to the proportion of white, indigenous and black. The creation of social categories such as mestizo prieto, or mulato black lead 
to the dissemination of blackness into several mini groups and subgroups in which black was diminished in favor of the white and the indigenous. For example, being classified as a mulato was socially worse than being identified as white, yet it was a higher social position than being classified as black.

At this moment, the mestizo categories become a buffer zone between the extremes of blackness and whiteness. When the census incorporated mestizo categories such as - mestizo blanco, mestizo prieto, mulato lobo- people were required to self-identify into one category. Aguirre points out that many tried to avoid being categorized or included as black due to the social consequences it entailed. Being categorized as black would deprive them from accessing to some spaces and benefits. A direct consequence of this adjustment was that official accounts of that period presented a drastic reduction of the presence of blacks in favor of the other two races, and so reversing the percentages presented in the previous paragraph. Official documents showed a small population of blacks because those documents did not account for the blackness present in the different new categories included in the census. In other words, by this time mestizaje was - consciously or unconsciouslyalready being used as a whitening strategy rather than an inclusive one.

As discussed above, the idea of mestizaje, understood as the mixture of different races and cultures, has been present in Mexico for centuries. However, it was not until the articulation of the post-revolutionary identity that it became an essential part of the new national imagined community. In contrast to other places in the world in which mestizaje has been seen as an accident, in Mexico in particular and in Latin America in general it has been claimed as "the essence, the central line" (Retamar 9). This idea of Latin American uniqueness in term of its racial configuration started with Simón Bolivar at the beginning of the $19^{\text {th }}$ Century, when the region was articulating its own identity in contrast with Spain. Following Bolívar, José Martí, another prominent Latin American intellectual in the second half of the $19^{\text {th }}$ century, expanded the notion of mestizaje as a fundamental essence of Latin America heritage. By envisioning mestizaje as a progressive action, he proclaimed in Our America that the rise of the mestizo will guarantee Latin American autonomy. Bolívar and Martí's notions of mestizaje had a large impact on successive generations of intellectuals in Latin America who tried to make sense of Latin America's complex racial and multicultural reality. Antonio Cornejo-Polar, a Peruvian scholar, wrote that "mestizaje was a conciliatory and comforting utopia that seems to gather into one unique torrent of many rivers that converged in this physical spiritual geography we call Latin America" (Cornejo-Polar 23). However, scholars agree that the greatest articulation of Bolívar and Martí's ideas into a discourse is La raza cósmica: misión de la raza iberoamericana (The Cosmic Race: Mission of the Ibero-American Race) written by José Vasconcelos.

The Cosmic Race fully developed the ideology of mestizaje and "tied political and aesthetic self-definition and assertion to a racial discourse at both the national and regional levels" (Miller 27). Vasconcelos' conception of mestizaje transcended its material aspect 
—exploited by Bolívar and Martí- by adding a spiritual perspective. In this sense, The Cosmic Race does not exclusively call for a "race in the biological sense, but as an attitude" (Zea 23). The compromise of these two aspects -biological and spiritual_ became the means for the construction of a unified nation. According to Castro's study, Mestizo Nation: Culture, Race, and Conformity in Latin American Literature, it is precisely this possibility of reconciliation that made mestizaje the way to "conceptualize the creation of a unitary nation from a heterogeneous population" (21). In the post revolutionary period of the 1920 s, mestizaje is not only a discourse to differentiate Latin America from an external enemy —namely colonial power or the USA - but the very basis to build a new, united, stronger national identity: the Mexican identity.

Mexico's current national official racial discourse was constructed and imposed over the general public at the end of the Mexican Revolution in the 1920 s. At that time, a group of modernizing intellectuals ${ }^{8}$ —whose most prominent official was the minister of education José Vasconcelos- faced the task of creating a new identity for the fragmented country. It was urgent to find a thread that would incorporate the whole Mexican society under a common ideal, so the country could be unified leaving behind the social and racial stratifications created during the colonial period such as criollos, españoles, indigenas, mestizos, mulatos, and negros. Thus, the project of mestizaje proposed by post-revolutionary intellectuals aimed at the elimination of racial distinctions, claiming mixture as the basis of the Mexican population and identity. At the same time, Mexican officials' discourse promoted "racial and cultural intermixture' as the only way to create homogeneity out of heterogeneity, unity out of fragmentation, a strong nation that could withstand the internal menace of its own failures to overcome the injustices of its colonial past" (Alonso 462). However, this discourse did not increase the actual representation of the different ethnic groups. On the contrary, it allowed elites to construct a deceitful image of a common nation while continuing to exploit the indigenous and black population.

In his book Deep Mexico, Silent Mexico, Claudio Lomnitz explores how the articulation of an immemorial past -what he calls depth- and silences are mutually implicated in the nation. "Images of a nation's rootedness are also used to displace or ignore particular claims." (xiii) In other words, each articulation of a nation displaces, ignores and, in worst cases, silences large portions of the population to the benefit of the imaged chosen by those in power. One can clearly see this in Vasconcelos' articulation of mestizaje since through the Cosmic Race, whiteness is exalted, portrayed as active and developed while indigenous and blacks are described in many negative terms. They are generally exposed as passive and recessive, "El blanco ha puesto al mundo en situación de que todos los tipos y todas las culturas puedan fundirse" (Vasconcelos 4). (The White man has put the world in a situation in which all types and cultures can mix). Besides creating the opportunity for the mixture, the whites also created "una raza nueva con el indio y con el negro" (5) (A new race with the 
Indian and the black). Though Vasconcelo advocates mixture and cultural acceptances, the truth is that the fusion of indians, blacks and whites is not presented as such. Instead, it is described as an incorporation of "the best features of blacks and Amerindians races into the criollo mainstream" (Castro 22). In this sense, mestizaje is, in fact, very close to the process of acculturation, in which the relationship between the parts involved is still determined by a power structure.

This inequality is also explicit in the contributions that each race is making to the coalescence to come:

How different the sounds of the IberoAmerican development! They resemble the profound scherzo of a deep and infinite symphony: Voices that bring accents from Atlantis; depths contained in the pupil of the red man, who knew so much, so many thousand years ago, and now seems to have forgotten everything. His soul resembles the old Mayan cenote of green waters, lying deep and still, in the middle of the forest, for so many centuries since, not even its legend remains any more. This infinite quietude is stirred with the drop put in our blood by the Black, eager for sensual joy, intoxicated with dances and unbridled lust... The clear mind of the White, that resembles his skin and his dreams, also intervenes. (22) ${ }^{9}$

Vasconcelos turns to nature when describing indians and blacks. However, he comes back to rationality when referring to whites. When referring to the indian race, Vasconcelos sentences that their time has already past; not even its legend remains. Regarding the black race, it is represented through sexual and barbaric stereotypes, and as being dominated by carnal passions. They are so wild that just one drop is all that they will pass on to the mestizo race. Finally, the white race will organize and makes sense of this chaos. This description of the mestizaje not only denies an active participation of the black race, it also perpetuates one dimensional racist images.

Throughout the book there is an emphasis on the superiority of the white race. Once white intellectual superiority is established, the text emphasizes the indigenous role mainly by reclaiming their ancestry. In his essay "L'Indigénisme et la marginalisation des noirs en Amérique latine" ("Indigenism and marginalization of black people in Latin America"), Victorien Lavou Zoungho explores the various effects the attempt to reclaim the role of indigenous groups had on other racial and ethnic groups also present in Latin America. He claims that "ese mismo afán de desagraviar a los indios contribuyó indirectamente a ocultar todavía más la presencia y las reivindicaciones de los negros" (62). ${ }^{10}$ Vasconcelos' cultural perspective of mestizaje was a façade that allowed "the oppression of Amerindians and black groups under the banner of their incorporation into the national communities; that is a cover up for ethnocide" (75). Zoungho argues that the white race was the only beneficiary in The Cosmic Race and in the mestizaje ideology in general. In his analysis, indians and blacks were equally eroticized, marginalized and used for the convenience of the white ruling elites. However, further reading of the text challenges and negates this conclusion. I argue that although there is a certain amount of negation and 
suppression of the indian role in the formation of mestizaje, they were incorporated into the mestizaje ideology to a greater extent than the black race.

Though, as we have seen, Vasconcelos originally acknowledges the contribution-one drop of blood-of the black race, later on in the book he proceeds to erase its presence and minimize its contribution. His articulation of the Mexican post-revolutionary nation in The Cosmic Race highlights the contributions of the white race while it silences blackness. He points out that the presence of people of African descent is very minimal, and those black people who exist are already mixed. Also, when describing the actual process of mixture, he simply leaves the black race out and acknowledges the white for "profusely spreading White ancestry through the soldier who began a native family, and Occidental culture through the doctrine and example of the missionaries who placed the Indians in condition to enter into the new stage, the stage of the world One" (17) ${ }^{11}$. The Cosmic Race presents an illusion of multiplicity and racial integration - parallel to the one created by the post-revolutionary national imagined community - but its discourse actually "erases by omission the ethnic African heritage of Mexican mestizaje while reinforcing the Cosmic Race belief that blacks and their "minor" ethnic legacy have been "integrated" or disappeared through absorption into a major European based culture" (Jackson 56). This same illusion is apparent in Memin Pinguín as evidenced by the character's intrepid experiences, and the reader of the comic strip receives this illusory message as well.
At first sight the images stamped on the comic strip depict the post-revolutionary imagined community, and present the Mexican nation as a mixed, multiracial society in which blacks, indians and whites interact on a daily basis and share the same spaces. Memín and his friends live in the same neighborhood, participate in the same activities and share the typical concerns of a school boy whose life consists of attending school, doing homework and playing with friends. Each race that contributes to the mestizo society, as conceived in The Cosmic Race is present in the book. However, as Benedict Anderson argues, the horizontal comradeship within the imagined community is not such a manifestation of egalitarianism and its appearance hides a strong power structure and discrimination. Memín Pinguín as a comic strip and its protagonist present metaphors that have been in use for a long time to undermine blackness. Robert Mckee Irwin, in his essay "Memín Pinguín, Rumba and Racism: Afro-Mexicans in Classic Comics and Films", suggests that at the end of each episode there is a clear moral which "teach[es] racial tolerance on multiple occasions" (253). I argue that these little morals, though present, fall short. They are included in the comics as a strategy to preserve the superficial image of fraternity among the actors of the imagined community, while at the same time, they conceal greater acts of inequality. They denounce blatantly racist acts performed by specific characters, but at the same time, there are a lot of imagery and everyday interactions tinted by the same racial standards which are overlooked, accepted and even encouraged. Episode after episode, Memín is 
consistently presented as an inferior burlesque character without agency of his own. His appearance is laughable. His grades are the lowest and his actions-when productive-are directed by authority figures.

The classroom described at the beginning of this essay is the setting for a lot of the adventures protagonized by Memín and his three friends. The characters are: Memín; Carlangas-nickname for Carlos, who lives with his widowed mother close to Memín; Ernestillo, the poorest of the four friends who sometimes wanders the streets without shoes; and Ricardo who is part of a wealthy family "whose progressive-thinking father believes, to the chagrin of his mother, that it will be healthy for him to study in a public school" (McKee Irwin 251). These four friends represent on a small scale the racial interweaving and attitudes occurring in Mexico: black -Memínand white -Ricardo- represent the extremes of the spectrum, while Carlangas and Ernestillo with their mixed features stand for the present and future: the mestizo.

Though the four school boys spend most of their time together, and are given relatively the same amount of time in the comic, Memín always stands out. For instance, his physical features are exaggerated making him look like a "bug-eyed, big-lipped halfhuman, half-chimp hybrid" (Asim 1). This practice by itself might not call our attention, for it is common practice in cartoons, caricatures and comic strip strips to achieve comedy or to point out certain features in the hero or protagonist. Moreover, the stereotypical presentation of blacks as monkeys, chimps, is not unique to this comic. Little Black Sambo and Aunt Jemima could be Memín and Eufrosina alter egos in the visual culture in the United States. There are also images in Latin America which resemble Memín's representation, like for example the Cuban icon Mamá Inés ${ }^{12}$. However, in the Mexican case, these exaggerations, which make Memín a laughable figure, contrast clearly with the realistic and sober portrayal of the other characters. While his eyes, nose and lips are disproportionately big, the rest of his body is excessively small. He is half the height of his classmates. In different vignettes he is standing up in the middle of the classroom while the rest of the students who are sitting in their chairs still look taller than him.

Memín's "half-chimp" appearance sets him apart from the rest of the characters in the comic. Compared to the rest, he does not look even reasonably human. Memín is dehumanized up to the point where it is not possible for the reader to see him as a representation of a "real" human being who is part of the Mexican society in which they live. However, Carlangas, the teacher or any other character could be identified as archetypical characters representing different sections of the Mexican mestizo society. For instance, Ricardo and his wealthy family distinctively represent the white - with his handsome features, intelligence and money. Ernesto is an exemplary student but the poorest of all. This character stands as an example of the potential of the mestizo race which is to be developed. By dehumanizing Memín and only he, the comic strip is perpetuating the stereotypical image presented in Vasconcelos' mestizaje that blackness is bad, ugly not beneficial to Mexican society 
and will eventually disappear. This dehumanization also marks Memín -and blackness- as foreign. Reinaldo González defends the fact that Vargas Dulche created Memín as a reaction to the negrista movement in $\mathrm{Cuba}^{13}$. "Su creadora, la escritora Yolanda Vargas Dulché, tuvo como modelo un negrito cubano, de ojos enormes, labios carnosos y orejas prominentes, parecido a muchos niños que conoció en La Habana de los años 30." (González) (Her creator, the writer Yolanda Vargas Dulché use as model a little black Cuban, with big eyes, lips and prominent ears, similar to a lot of kids that she met in La Habana in the 1930s). Memín is not a Mexican, he is a visitor, a tourist and an outsider. Therefore, he is presented as part of the future, but as temporal presences which will eventually go back to where it came from or disappear.

Memín is also presented as silly, simple minded, good for nothing. He would rather spend the day running around and getting in trouble than studying. In the course of the 300 episodes, he gets expelled from school several times, and he always regrets the day that he has to go back to the classroom. In an episode, the teacher talks to him about the purpose of studying. Memín answers: "con letras o sin ellas, igual de sabroso le sabría a un león...i para qué estudio?" (225-1) ${ }^{14}$. The class laughs at Memín's wit and the teacher immediately expels him. The following day Eufrosina -Memín's motheraccompanies him to ask for mercy. Finally, Professor Romero allows Memín to come back to the class making the following remark: "Bien Doña Eufrosina no se preocupe. Le aseguro que Memín entrará en razón y cuando menos figurará como el último de la clase"
(Memín 225-12) ${ }^{15}$. This passage again can be read as a reflection of the role assigned to blackness within mestizaje. It cannot be completely eliminated. At least it has to be acknowledged, but it is enough to be ranked last, weakest and as a meaningless link.

Don Romero is not the only character who reacts to Memín's behavior and mischievous actions with a he-doesn'tknow-better attitude. Even his best friends patronize him. Behind these attitudes lies the presupposition that black is inferior and needs to be guided. For this reason, this paternalistic attitude is as bad as the openly racist comments of the other characters. Both of them deny the possibility that the racial group he represents has equal rights to other groups. Without exception, the characters that represent the white race either present an openly racist behavior toward Memín-and mestizos-or assume a paternalistic attitude. The first group is criticized and ridiculed by other characters or by the way they are portrayed in the comic strip while the later are presented as the voice of reason.

For example, Doña Refugio -Ricardo's mother- is depicted as very pale, blue-eyed and blond. In an episode in which Memín is invited to Ricardo's house, Doña Refugio instantly faints when she sees Memín. Ricardo's father -Rogelio- comes to help her and when she finally recovers she exclaims: "Te aseguro que vi un mico... era espantoso; tenía los ojos como un toro" (Memín 4) ${ }^{16}$. Rogelio smiles and comforts his wife. A few episodes later, a similar situation happens. In this case Memín is visiting a friend of Carlangas' father. While they are waiting to have dinner, the son of 
the host arrives and exclaims irately "¿Quién permitió a este negro sentarse en nuestra mesa?... ¡Lárgate!... Los negros no deben mezclarse con nosotros" (Memín 299) ${ }^{17}$. In this case, there is no follow-up or answer of any kind but later on in the episode the character that made the comment is embarrassed in front of everyone, and he is also proved wrong.

These repeating rectifications have been interpreted by some critics as proof that Memin Pinguin is not a racist comic strip but rather that it educates and raises awareness in the audience. For example, Robert Irwin in his essay "Memín Pinguín, Rumba, and Racism" argues that by scolding and embarrassing the openly racist characters the comic strip "preaches time after time that racism is wrong" (Irwin 253). While Irwin defends the way the comic strip preaches race harmony, I argue that only the blatantly racist acts are denounced. Though some characters are scolded for their acts, there are other less obvious forms of racism and racial oppression that are overlooked and even presented as the proper way to act.

For instance, Professor Romero's paternalistic attitude towards Memín can also be seen in Ricardo's father and Don Nicéforo Melquiades. These two authority figures in the comics show an apparently tolerant, inclusive position towards Memín but they never get to the point of treating him like any other character in the comic. The case of Nicéforo Melquiades is quite curious in this regard as well. This character only appears in three episodes. He is a fifty year old homeless man who appears in Memín's life while his mother is in the hospital. Melquiades is a poor but very wise man who makes it his task to make him the top student of his class: "de mi cuenta corre que se convierta en el primero de su clase" (Memín número 235-7). Thanks to Nicéforo's guidance Memín learned all the rivers and capitals of all the European countries. After a week of study Memín becomes the hero of the class, giving the right answers to all the questions. Don Nicéforo feels he has accomplished his taskto show Memín the right way-and leaves the house and the comic strip. However, immediately following Nicéforo's good bye, Memín suddenly loses his way and becomes the same goodfor-nothing and gets expelled from the class. This event shows, once again that blackness by itself has no future in the mestizo community. Only with the strict supervision of a wise white man can blacks succeed. However, once that supervision stops, so will the advances of the blacks because they do not know by themselves what is best for them.

All in all, Memín's character and his presence are the protagonists of the comic strip but not as a way of pointing out the contribution and active role of blackness in the Mexican mestizo society but quite the opposite. As it happens in Vasconcelos' depiction on The Cosmic Race, the character of Memín, and by enlarge blackness, stands as one isolated drop that will eventually be diluted. At first sight, the classroom and neighborhood seem to represent the multiplicity and racial integration promulgated by the post-revolutionary national imagined community. However, when considered more in depth, one realizes that the interactions among the different races (black, Indian, and white) are in reality hierarchical and patronizing at best. Memín falls short 
once and again in the eyes of the rest of the characters and therefore in the eyes of the readers. Only when closely monitored by a white male authority figure, Memín is able to accommodate the standards but, even under great guidance, he is not able to excel. His appearance is mocked by others when the rest of the characters are not. Memín's classmates and teachers look down on him for his lack of skills at school and mischievous tendencies. On the other hand, the rest of his classmates are rarely if ever critique for similar behaviors. By making such a big difference on the way authority figures react to and behave towards Memín and the rest of the boys at school, the comic strip is perpetuating a patronizing and "he doesn't know better" attitude towards blackness also presented in Vasconcelos' work.

Therefore, the images and discourse present in Memin Pinguin are a re-enactment of the whitening ideology of mestizaje proposed by Vasconcelos' The Cosmic Race. The apparently harmonious yet deceitful image of racial democracy presented in the comic strip ultimately reinforces stereotypical and discriminatory ideas towards blacks. By reproducing the aesthetics proposed in The Cosmic Race and imposing it on the general public, the government denied the different races the possibility to determine their own racial identity and political articulation. Moreover, the government also eliminated the possibility for future political claims based on race, racial differences or racial discrimination. Mexico is a mestizo nation, there are no racial distinctions there is only one race. The comic strip Memín Pinguin works as a way of perpetuating the teachings of
Vasconcelos' mestizaje. It provides an image of racial democracy but at the same time the attitudes and actions of the characters in the comic strip show a whitening discourse. It is true that openly discriminatory comments are rejected or punished in the comic strip; however, paternalistic attitudes are applauded, and they undermine the little social or political agency blacks could aspire to have.

\section{Notes}

1 Guillermo's pale skin and dress are indicators of his upper class and wealthy family.

2 The character was created by Yolanda Vargas Dulché. It was originally drawn by Alberto Cabrera in 1943, and later was drawn by Sixto Valencia Burgos. There are different theories and opinions about the influence of each of these members to the appearance of Memín. See McKee Irwin, Robert.

3 In summer 2005 Mexican government issued a series of five postage stamps commemorating the figure of Memín Pinguín, one of the protagonists in the comic.

4 See Aguirre Beltrán, Gonzalo.

5 Virreinato de la Nueva España or Viceroyalty of New Spain was the first of four viceroyalties created to govern Spain's territories in North and Central America. It was ruled by a viceroy from Mexico City who governed many territories on behalf of the King of Spain. It included present American Southwest as well as present day Mexico.

6 "Being that so few blacks were brought into Nueva España, the mestizos probably represents about $7 / 8$ of the castas" (Humboldt).

7 For example, Aguirre points out that during these centuries the total population of 
blacks and whites together were approximately $2 \%$ of the total population, while the $98 \%$ were indigenous. (Aguirre 198).

8 As part of the reconstruction process underwent by Mexico during and after the Mexican Revolution, a group of intellectuals called El Ateneo de la juventud was formed by Alfonso Reyes, Antonio Caso, Pedro Henríquez Ureña, and Samuel Ramos among others. See Llinás Alvarez, Edgar for more information on this matter.

9 "¡Cuán distintos los sones de la formación iberoamericana! Semejan el profundo scherzo de una sinfonía infinita y honda: voces que traen acentos de la Atlántida; abismos contenidos en la pupila del hombre rojo, que supo tanto, hace tantos miles de años, y ahora parece que se ha olvidado de todo. Se parece su alma al viejo cenote maya, de aguas verdes, profundas, inmóviles, en el centro del bosque, desde hace tantos siglos que ya ni su leyenda perdura. $Y$ se remueve esta quietud de infinito con la gota que en nuestra sangre pone el negro, ávido de dicha sensual, ebrio de danzas y desenfrenadas lujurias... Interviene asimismo la mente clara del blanco, parecida a su tez y a su ensueño" (Vasconcelos 18).

10 Same urge to make amends to the indians indirectly contributed to hiding even more the presence and demands of the blacks.

11 "Prodigando la estirpe blanca mediante el soldado que engendraba familia indígena y la cultura de Occidente por medio de la doctrina y el ejemplo de los misioneros que pusieron al indio en condiciones de generar en la nueva etapa, la etapa del mundo Uno" (Vasconcelos 15).

12 Mama Inés is the protagonist of the classic rumba song "Ay Mamá Inés". Her image is that of a "hefty Afro-Cuban woman who wears a typical bata cuba- na and a kerchief on her head, drinks coffee, and smokes cigars." (Mckee Irwin 254). This image has been used by coffee companies in Puerto Rico and the Dominican Republic.

13 The negrista movement was formed by a group of Latin American and Caribbean writers and poets who incorporated black themes of folklore, religious practices, music, and dance in their work. Writing principally from the 1930s to the 1950s, the group included such writers as Nicolas Guillén, Ramón Güirao and José Zacarías Tallet of Cuba. For more see Lesley Feracho "Legacy of Negrismo/Negritude: Inter American Dialogues."

14 With knowledge or without, I would be equally tasty to a lion... Why should I study?

15 Well, don't worry Doña Eufrosina. I assure you Memín will be reasonable and at the very least will remain in the class as the student with the lowest marks

16 I assure you I saw a monkey...It was horrifying. He had the eyes of a bull

17 Who let this black boy sit at our table?... Get out of here!... Blacks should not mix with us!

\section{Bibliography}

Asim, Jabari. "Stamp of Disapproval for Mexico". The Washington Post. July $5^{\text {th }}$ 2005. http:// www.washingtonpost.com/wpdyn/content/blog/2005/07/05/ BL2005070500674.html. <accessed July $25^{\text {th }} 2010>$

Adorno, Theodor W. "Schema of Mass Culture." The Culture Industry: Selected Essays on Mass Cuture. Ed. J.M. Bernstein. London: Routledge, 1991. 53-85. 
Aguirre Beltrán, Gonzalo. La población negra en México. México: Tierra Firme, 1972.

Alonso, Ana María. Conforming Disconformity: "Mestizaje", Hybridity, and the Aesthetics of Mexican Nationalism. 459-490.

Anderson, Benedict. Imagined Communities: Reflections on the Origin and Spread of Nationalism. London: Verso, 2006.

Aurreconechea, Juan Manuel and Armando Bartra. Puros cuentos III: historia de la historieta en México, 1934-1950. Mexico City: Consejo Nacional para la Cultura y las Artes/Grijalbo, 1994.

Castro, Juan E. de. Mestizo Nations: Culture, Race and Conformity in Latin American Literature. Tucson: University of Arizona Press, 2002.

Cornejo Polar, Antonio. The Multiple Voices of Latin American Literature. California: Doe Library, University of California, 1994.

Feracho, Lesley. "The Legacy of Negrismo/Negritude: Inter-American Dialogues". Langston Hughes Review 16.2 (1999-2001): i-xx.

Fernández Retamar, Roberto. "Caliban: Notes towards a Discussion of Culture in our America". The Massachusetts Review 15.72 (1971): 7-72.

González, Reynaldo. "Memín Pinguín provoca un incidente diplomático," La Jiribilla 218 (July 2005), online at http://www.lajiribilla.cu/2005/ n218_07/218_03.html (accessed 15 March 2007).

Hernández Cuevas, Marco Polo. "La población negra de México: Parte del discurso blanqueador para "poner al negro en su lugar." Afro-Hispanic Review 23.1 (Spring 2004): 3-9.
"Memín Pinguín: uno de los comics mexicanos más populares como instrumento para codificar al negro." Afro-Hispanic Review 22.1 (Spring 2003): 52-59.

Humboldt, Alejandro de. Tablas geográficas políticas del reino de Nueva España que manifiesta la superficie, población, agricultura, fábricas, comercio, minas, rentas y fuerza militar. México, diciembre de 1803, Archivo General de la Nación, Vil, 72, Exp. 266.

Jackson, Richard L. "Black Phobia and the White Aesthetic in Spanish American Literature." Hispania 58 (September 1975): 467-480.

Lavou Zoungho, Victorien. "L'Indigénisme et la marginalisation des noirs en Amérique latine". Imprévue, 1993: 61-77.

Llinás Alvarez, Edgar. Revolución, Educación y Mexicanidad: la Búsqueda de la Identidad Nacional en el Pensamiento Educativo Mexicano. México: Universidad Nacional Autónoma de México, 1979.

Lomnitz, Claudio. Deep Mexico, Silent Mexico: An Anthropology of Nationalism. Minneapolis: University of Minnesota Press, 2001.

McKee Irwin, Robert. "Memín Pinguín, Rumba, and Racism: Afro-Mexicans in Classic Comics and Film." Hemispheric American Studies. Eds. Levander, Caroline F. and Levine, Robert S. London: Rutgers University Press, 2008. 249-266.

Miller, Marilyn Grace. Rise and Fall of the Cosmic Race: The Cult of Mestizaje in Latin America. Austin: University of Texas Press, 2004.

Vargas Dulché, Yolanda (arguments) and Sixto Valencia Burgos (illustrations), Memín Pinguín. México 
Vid, 1964-Present (372 Installments).

Memin Pinguin. México: DC Comics, 4 (13 May 2002). Memín Pinguín. México: DC Comics, 1 (22 April 2002).

Memin Pinguín. México: DC Comics, 208-209 (10-17 April 2006).

— Memin Pinguín. México: DC Comics, 128 (27 Sept. 2004).
. Memín Pinguín. México: DC Comics, 235-7 (4 Oct. 2008).

Vasconcelos, José. Cosmic Race: A Bilingual Edition. Trans. Didier T. Jaen. JHU Press, 1997.

Zea, Leopoldo. "Vasconcelos y la Utopía de la Raza Cósmica". Cuadernos Americanos 37.1 (1993): 23-36. 
